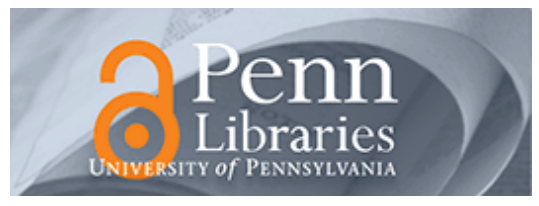

Manuscript Studies

\title{
The Strange Afterlife of Vidyāpati Thākura (ca. 1350-1450 CE): Anthological Manuscripts, Linguistic Confusion, and Religious Appropriation
}

Christopher L. Diamond

University of Washington

Follow this and additional works at: https://repository.upenn.edu/mss_sims

Part of the Asian History Commons, Hindu Studies Commons, Musicology Commons, and the South and Southeast Asian Languages and Societies Commons

\section{Recommended Citation}

Diamond, Christopher L. (2019) "The Strange Afterlife of Vidyāpati Thākura (ca. 1350-1450 CE):

Anthological Manuscripts, Linguistic Confusion, and Religious Appropriation," Manuscript Studies: Vol. 4 : Iss. 1 , Article 4.

Available at: https://repository.upenn.edu/mss_sims/vol4/iss1/4 


\title{
The Strange Afterlife of Vidyāpati Thākura (ca. 1350-1450 CE): Anthological Manuscripts, Linguistic Confusion, and Religious Appropriation
}

\begin{abstract}
This article examines the difficult aspects of working with anthological manuscripts and printed editions of lyrical vernacular poetry in South Asia by focusing on the textual reception of Vidyāpati Thākura. In his own life, Vidyāpati wrote technical treatises in Sanskrit, historical narratives in Apabhraṃśa, and a corpus of lyrical poems (padas) and two dramas in the vernacular Maithili language. While his technical works remained relatively static and limited in their circulation, Vidyāpati's lyrical poems had a more enduring and geographically widespread effect on the languages, literatures, and religions of Mithilā and Eastern India (Bengal, Orissa, and Assam). The anthologies of padas, usually called "padāvalī's", whatever their historical manifestation or locality, were usually collections of disconnected padas without contextual narratives or explanations.

This analysis focuses on the difficulty of working with free-standing small lyrical poems, which were never conceived of as unified textual entities, in both organized padāvalīs and small disposable manuscript handbooks (pothīs). The padas were used pragmatically by elite poets, devotional saints, and musicians from the 15 th century CE onwards. This creates problems when one tries to trace physical remains and textual sources from this period. There exists a gap between the Maithili padāvalis of the 16 th and 17 th centuries and the Bengali Vaișnava padāvalīs writing in a hybrid Bengali-Maithili kuntsprache of the 18 th and 19 th centuries. Since the linguistic and poetic variations and total number of attestations are so extensive, what relationship can be inferred between the Maithili padāvali tradition and later anthologies based on manuscript and other textual evidence? I argue for a strategy of closely reading the variances and additions to the bhanitā (poetic signature) that reveal an appeal to the courtly prestige of Mithilā, even in the devotional communities of Bengal.
\end{abstract}

\section{Keywords}

Manuscript studies, India, Musicology, Bengali Literature, Religion of Bengal, Vaișṇava literature, liturgical manuscripts, methodology of philology, court literature, vernacular literature in South Asia 


\section{MANUSCRIPT STUDIES}

A Journal of the Schoenberg Institute for Manuscript Studies

VOLUME 4, N UMBER 1

(Spring 2019)

Manuscript Studies (ISSN 2381-5329) is published semiannually

by the University of Pennsylvania Press

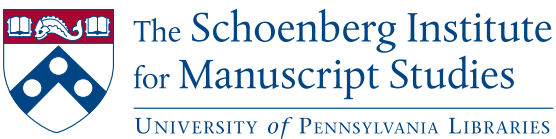




\section{MANUSCRIPT STUDIES}

VOLUME 4 , N UMBER 1

(Spring 2019)

ISSN 2381-5329

Copyright (C 2019 University of Pennsylvania Libraries

and University of Pennsylvania Press. All rights reserved.

Published by the University of Pennsylvania Press, 3905 Spruce Street, Philadelphia, PA 19104.

Printed in the U.S.A. on acid-free paper.

Manuscript Studies brings together scholarship from around the world and across disciplines related to the study of premodern manuscript books and documents, with a special emphasis on the role of digital technologies in advancing manuscript research. Articles for submission should be prepared according to the Chicago Manual of Style, $16^{\text {th }}$ edition, and follow the style guidelines found at http://mss.pennpress.org.

None of the contents of this journal may be reproduced without prior written consent of the University of Pennsylvania Press. Authorization to photocopy is granted by the University of Pennsylvania Press for libraries or other users registered with Copyright Clearance Center (CCC) Transaction Reporting Service, provided that all required fees are verified with CCC and paid directly to CCC, 222 Rosewood Drive, Danvers, MA 01923. This consent does not extend to other kinds of copying for general distribution, for advertising or promotional purposes, for creating new collective works, for database retrieval, or for resale.

\section{SUBSCRIPTION INFORMATION:}

Single issues: $\$ 30$

Print and online subscriptions: Individuals: $\$ 40$; Institutions: $\$ 92$; Full-time Students: $\$ 30$ International subscribers, please add $\$ 18$ per year for shipping.

Online-only subscriptions: Individuals: $\$ 32$; Institutions: $\$ 80$

Please direct all subscription orders, inquiries, requests for single issues, address changes, and other business communications to Penn Press Journals, 3905 Spruce Street, Philadelphia, PA 19104. Phone: 215-573-1295. Fax: 215-746-3636. Email: journals@pobox.upenn.edu. Prepayment is required. Orders may be charged to MasterCard, Visa, and American Express credit cards. Checks and money orders should be made payable to "University of Pennsylvania Press" and sent to the address printed directly above.

One-year subscriptions are valid January 1 through December 31. Subscriptions received after October 31 in any year become effective the following January 1. Subscribers joining midyear receive immediately copies of all issues of Manuscript Studies already in print for that year.

Postmaster: send address changes to Penn Press Journals, 3905 Spruce Street, Philadelphia, PA 19104.

Visit Manuscript Studies on the web at mss.pennpress.org. 


\section{MANUSCRIPT STUDIES}

\section{A Journal of the Schoenberg Institute for Manuscript Studies}

VOLUME 4, N UMBER 1

\section{Articles}

In the Age of Non-Mechanical Reproduction:

Manuscript Variation in Early-Modern South Asia

Arthur Dudney, Neeraja Poddar

Manuscript Variations of Dabistān-i Maz̄āhib

and Writing Histories of Religion in Mughal India

Sudev Sheth

Power Permutations in Early Hindi Manuscripts:

Who Asks the Questions and Who Gives the Answers,

Rāmānand or Kabīr?

Heide Paunels

The Strange Afterlife of Vidyāpati Thākura (ca. 1350-1450

CE): Anthological Manuscripts, Linguistic Confusion, and Religious Appropriation

CHRistopher L. DiAmond

Prefatory Notes on Persian Idioms of Islamic Jurisprudence:

Reasoning and Procedures of Law-Making in Premodern

Islamicate India

Naveen Kanalu

Replication and Innovation in the Folk Narratives

of Telangana: Scroll Paintings of the Padmasali

Purana, 1625-2000

Anais Da Fonseca

Nectar or Arrow: Cases of Missense Textual Mutations in Early Kabïrian Padas

Zhang Minyu 
Manuscript Studies, Vol. 4 [2019], Iss. 1, Art. 4

iv | Journal for Manuscript Studies

"Publishing" and Publics in a World Without Print:

Vernacular Manuscripts in Early Modern India

Tyler Williams

\section{Reviews}

Kay Davenport. The Bar Books: Manuscripts Illuminated for Renaud de Bar, Bishop of Metz (1303-1316).

RICHARD A. LESON

Matti Peikola, Aleksi Mäkilähde, Hanna Salmi, Mari-Liisa

Varila, and Janne Skaffari, eds. Verbal and Visual

Communication in Early English Texts.

Lydia Yaitsky Kertz

Alpo Honkapohja. Alchemy, Medicine, and Commercial

Book Production: A Codicological and Linguistic Study

of the Voigts-Sloane Manuscript Group.

Winston BLACK

List of Manuscripts Cited 


\title{
The Strange Afterlife of Vidyāpati Țhākura (ca. 1350-1450 CE): Anthological Manuscripts, Linguistic Confusion, and Religious Appropriation
}

\author{
Christopher L. Diamond \\ University of Washington
}

\section{The Problem with Padas}

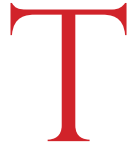

HE STUDY OF PREMODERN manuscript traditions of lyric poetry and poetic anthologies (padas and padāvalīs) from eastern India presents a paradox. As one of the most widespread of the padāvali traditions and one of the earliest North Indian vernacular sources, the padas of Vidyāpati (a Maithili poet of the early fifteenth century CE) accurately represent the kind of textual paradox in question. Namely, that there exists a large number of small pothīs (loose-leaf manuscripts), without attribution of scribe or patron, scattered around the region, large poetic compendiums from Bengal (pada-samgrabas), and conversely, an abundance of later period texts in Bengal belies the scarcity of attested manuscripts from the period between Vidyāpati's life and his renewed popularity during the eighteenth and nineteenth centuries CE in both Mithilā and Bengal. This incongruity not only has stymied a stemmatological study of the transmission and circulation of Vidyāpati's vernacular corpus between Mithilā and wider eastern India, but also has led to scholarly neglect of small, semi-disposable potbīs 
of padas across the region. ${ }^{1}$ The conflict between the self-presented narrative of the manuscript tradition, the narratives of long-accepted literary historians in the modern period, and popular traditions presents an opportunity to scrutinize the fractured process of memory and meaning making for premodern literary texts.

The incongruence caused by the lack of sources from the earlier Maithili period and the profusion of sources from the later Bengali period raises several questions. With only a handful of padas occurring across all, or the majority, of older sources, what is the internal relationship among the "earlier" Maithili sources, and what kinds of textual development can or should be mapped? In the eighteenth through nineteenth centuries $\mathrm{CE}$, the number of padas attributed to Vidyāpati in Bengali padāvalī collections multiplied dramatically. Though only rarely coinciding with the older Maithili sources, padas attributed to Vidyāpati occur in large numbers in both large pada-samgrabas (pada collections) and small padāvalī pothīs. In the premodern period, the attribution of poems to early and more authoritative poets was a frequent phenomenon. ${ }^{2}$ This created problems for any would-be stemmatologist trying to assess authenticity. Preferring older sources that exclusively feature the padas of Vidyāpati, most modern scholars have discounted and ignored the widely distributed and extant potbīs containing padas of Vidyāpati along with those of other lyric poets. Instead of trying to find the "real Vidyāpati" by relying on stemmatological studies of textual transmission, what can these "fake" Vidyāpatis in later centuries tell us about the poetic aspirations and designs of their actual authors and readers? What quality of Vidyāpati's do they emulate or state explicitly?

The compilers and authors of both Maithili and Bengali padāvalīs and potbīs capitalized on the literary prestige and authority of Vidyāpati and the

1 There is a larger discussion to be had as to the assumption of the eastern regions of South Asia (Bihar/Jharkhand, Bengal, Orissa, Assam, and parts of Nepal) as a discrete cultural unit. 2 A similar phenomenon was established for the tradition of famed Vaiṣnava poet-saint Sūr Dās by John S. Hawley. This is especially true for the colossal Sur Sägar collection of the poet's verses, which was sometimes expanded to seven to nine thousand poems; see John Stratton Hawley, Sūr Dās: Poet, Singer, Saint (Seattle: University of Washington Press, 1984), 35-63. 
court of his patron Siva Simpha (r. 1410-1414 CE). ${ }^{3}$ Thematic and narrative elements that were adapted from the courtly Maithili culture of Vidyāpati to the Vaișnava Bengali milieu feature most prominently in the bhanitās of each pada, which are often dedicated to the kings and queens of the court of Mithilā. ${ }^{4}$ While a few dozen padas occur across the major Vidyāpati sources, the small, but numerous pothīs of later centuries rarely feature any but the most famous padas. Evaluating the language, literary style, and historical references of the bhanitās across these sets of manuscripts uncovers a tradition of literary self-fashioning by the compilers and consumers within the Vidyāpati tradition that hints at a more dynamic history of vernacular transmission and identity-making.

Though the approaches of this study could be applied broadly to lyric poetry collections from the early premodern to colonial periods, I have chosen to focus specifically on Vidyāpati due to his early date (ca. 1350-1450 $\mathrm{CE}$ ) in relation to other north and east Indo-Aryan vernacular traditions, the breadth of his influence in eastern India (from Nepal to Odisha, Assam to Bihar), and the independent textual histories of his poetry in Mithilā and Bengal. ${ }^{5}$ This article is an articulation of the status questionis of the Vidyāpati textual tradition and is an attempt to map the relationship between the sources for a Vidyāpati tradition, which are often considered in a segregated manner. After comparing a select pada that occurs in three of the Maithili padāvalì manuscript sources along with an "inauthentic" pada of a small pothī from nineteenth-century Bengal that features many commonalities, it becomes clear that it is impossible to develop any clear picture of direct transmission directly from Mithilā to Bengal (and by extension to Assam and Odisha) that does not selectively ignore a large number of manuscript

3 For a detailed introduction to the most famous king of the Oinvāra dynasty of Mithilā, see Upendra Thakura, History of Mithilā: From the Earliest Times to 1556 A.D., 2nd ed. (Darbhanga: Mithilā Institute, 1988 [1956]), 247-60.

4 A bhanita is a poetic signature distich that features as the last line of a pada.

5 I have provided a broad and average dating for Vidyāpati's life. Others have proposed shifting the timeline back a few decades, but most have said that Vidyāpati lived past the age of ninety. For a systematic summary of proposed dates, see Muhammad Shahidullah, "The Date of Vidyāpati," Indian Historical Quarterly 20, no. 3 (1944): 211-17. 
sources. An examination that considers the actual state of affairs of manuscripts (of all varieties) as they are currently accessible along with practices of memorialization serves to problematize long-held assumptions of historical continuity. Twentieth-century literary historians, often lionized because of their social status within South Asian literary institutions, claim an unbroken lineage between the "original" Maithili Vidyāpati and the Vidyāpatis who emerge in later centuries. This study attempts to reconstruct literary methods of self-presentation and memorialization on the part of the compilers, editors, and readers of the padas of Vidyāpati. Instead of taking the assumptions of literary historians literally, this study aims to take their imaginaries seriously and to investigate the methods of their construction.

This short study is not intended to be a comprehensive study of the Vidyāpati tradition in either the Maithili or Bengali/Brajabuli recensions. Even so, it is useful to provide a survey of the current status of manuscripts relating to the Vidyāpati tradition and to consider their relation to one another. ${ }^{6}$ This will progress to a close reading analysis of one of the very few padas that occur in the majority of Vidyāpati-related manuscripts. The final section of this paper concerns a pada found in a small nineteenthcentury poth $\bar{\imath}$ from the Asiatic Society of Bengal in Kolkata. This potbi, while "inauthentic" according to traditional perspectives, contains a reference to Vidyāpati’s famous patron, Śiva Siṃha, and his queen, Lakhimā Devi. This reveals an interesting impressionistic association on the part of the author between Vidyāpati and his patrons as a source of meaning and authority.

It is necessary to discuss his life and context briefly before turning to his manuscript and textual tradition. Said to be born in the village of Bisphī, in the Madhubanī district of Mithilā, Vidyāpati was closely associated with Oinvāra kings of Tirhut (ca. 1325-1556 CE), especially with Śiva Siṃha and

6 I have tried to consistently refer to simply "Vidyāpati” when I mean to evoke the historical figure and author and to refer to the "Vidyāpati tradition" when I intend to refer to the entire corpus and history of memorialization that is attached to the poet's name. 
his queen and later independent ruler Lakhimā Devī (r. 1416-1428/9). ${ }^{7}$ The courts of both monarchs are remembered in colonial and modern plays, novels, and film as the golden era of culture and scholarship in Mithilā. ${ }^{8}$ This contributes to the later assertions of this paper that Vidyāpati's memorialization is largely due to the imagined courtly culture of the Oinvāra court. As an orthodox brahmin-smārta (ritual specialist of the priestly caste) courtier of a small, quasi-independent Hindu kingdom, Vidyāpati's main intellectual and artistic contributions were a set of technical treatises on ritual and ethical issues (inheritance, letter-writing, and so on). ${ }^{9}$ Being versatile, Vidyāpati also composed two historical narratives (the Kìrttilatā [ca. 1420] and the Kirttipatāka) on the political and military exploits of Prince Kīrtti Siṃha. ${ }^{10}$ Vidyāpati's vernacular corpus includes between two hundred and three hundred padas and two small plays (Goraksavijaya and the Manimañjarī), which also contain lyric poems. ${ }^{11}$

7 The village of Bisphì is currently the site of several monuments and institutions dedicated to the memory of Vidyāpati. Along with a community and cultural center, several Śiva temples feature prominent pictures or statues of Vidyāpati within their precincts. For a full transcription of the much-discussed deed granting the village to the poet, see Vidyāpati-Padāvalì: Nepāl Se Prāpta Vidyāpati Ke Padom Kã Samgraba, 3 vols. (Pațanā: Bihāra-RāștrabhāṣāParișad, 2012), 1:19-20. Thakura, History of Mithilā, 259-61.

8 A prominent example of twentieth-century memorialization of the court of Śiva Simpha and Lakhimā Devī is the 1937 dual Bengali and Hindi production by New Theatres. This film cemented the Vidyāpati-Śiva Siṃha-Lakhimā triad as the central narrative of the padāvalìs backstory. In this case, the film features an illicit love triangle between the three. Interestingly, the Bengali version's lyrics, modeled as padas of Vidyāpati, were written by Kazi Nazrul Islam (1899-1976). Debaki Bose, Bidyapati/Vidyapati (Calcutta: New Theatres Limited, 1937).

9 The Vibhāgasāgara, the Likbanāvali, etc.

10 The Kìrttipatāka survives only as a single fragmented manuscript. This text's remains, edited last in 1960 by Umesh Mishra, would be important to reassess in the light of the padavvalì's association with Siva Simpha as both were patronized by the king and the former provides some historical context to his reign, including his military exploits against local representatives of the Sultanate. Umesh Mishra, ed., Kìrtipatāka (Allahabad: All India Maithili Sahitya Samiti, 1960). 11 There is some question as to whether Goraksavijaya in its entirety was composed by Vidyāpati, as its ascription is based on the contained padas in Maithili that bear Vidyāpati's name in the bhanitā. The Sanskrit and Prakrit prose text of the play do not contain any overt mention of an author. In either case it would be interesting to investigate this play as an additional site of memory construction around a possibly Nāth/Śaiva tradition of Vidyāpati. See Herman Tieken, Karin Steiner, and Heidrun Brückner, eds., "Songs Accompanied by 
Vidyāpati's legacy extends to other cultural spheres within premodern South Asia. He is cited in the 'Ain-ī Akbari of Mughal historian Abū al-Faẓl as a famous composer of the popular song genre of Bihar designated as "laccharis." 12 There is some confusion of whether a "lacchari" is identical to the more well-attested genre name of "nacāin." This refers to the erotic padas or life-cycle songs that are devoted to Śiva and the Goddess, both of which feature in the Maithili and Nepali padāvalī manuscripts and in oral performances. Bengalis Vaiṣnavas (a.k.a. Gauḍ̄ya Vaị̣navas) revere Vidyāpati for being a favorite composer of Kṛ̣ṇa songs of Caitanya (1486-1534). In the Caitanya-Caritāmrta of Kṛ̣̣ndās Kavirāja (b. 1496), Caitanya is described as both reciting and attentively listening to his disciples, Svarupa Dāmodara and Rāmānanda Rāya, recite the verses of Vidyāpati. ${ }^{13}$ The layered pedigree from secondary sources often obscured the accounts of Vidyāpati's Maithili works by historians of early vernacular eastern Indic literatures. It often had the effect of presupposing literary prestige and eminence when in reality we cannot say with any surety as to whether manuscript versions of Vidyāpati's padāvalī circulated as far and as deeply as has been claimed.

\section{The Maithili Manuscript Sources}

While Vidyāpati's memory is alive and well in contemporary South Asia, the actual trail of manuscripts falls short of leading us back to the "original"

So-Called Bhanitās in Dramatic Texts," Indische Theater: Text, Theorie, Praxis, Drama Und Theater in Südasien 8 (Wiesbaden: Harrassowitz Verlag, 2010), 63-75.

12 Jadunath Sarkar, ed.; Col. H. S. Jarrent, trans., 'Ain-I-Ākbari of Abul Fazl-I- 'Ällami (Calcutta: Royal Asiatic Society of Bengal, 1948), 3:266.

13 Rāmānanda Rāya (1504-1532) is also credited with inaugurating the Odia tradition of Brajabuli/Vaiṣnava poetry modeled after Vidyāpati and Old Maithili poetic standards. This is a decidedly Bengali/Maithili perspective that is often left out of Odia histories of their own literary canon. Neeta Jha, "Vidyāpati and His Followers," Maithili Studies: Papers Presented at the Stockholm Conference on Maithili Language and Literature, ed. W. L. Smith (Stockholm: Department of Indology, University of Stockholm, 2003), 10. Caitanya Caritāmṛta 1.13.40, 2.2.65, 2.10.113, 3.15.24-25, 3.17.4-7, and 3.17.58. Tony K. Stewart, ed.; Edward Dimock, trans., Caitanya Caritāmrta of Krṣnadāsa Kavirāja: A Translation and Commentary (Cambridge, MA: Department of Sanskrit and Indian Studies, Harvard University, 1999). 
Vidyāpati. Generally, three manuscripts from the earlier Maithili period (fifteenth to sixteenth centuries CE) have been used as sources for the Vidyāpati tradition. All but the earliest manuscripts have been destroyed or have disappeared. Even between the three earlier sources, only a handful of padas occur in all three. Similar problems of attribution occur in other early North Indian poet corpuses. In the case of the burgeoning Kabīr tradition across North and Western India between the fifteenth and seventeenth centuries CE, Callewaert describes interaction of oral traditions and scribalmanuscript culture, "act[s] like a fog and pollution, creating a nebulous environment in which is becomes difficult to find the original version of the songs." ${ }^{14}$ Like Callewaert, I seek to turn "fog” itself into insight.

\section{Nepal Manuscript}

The oldest and most "authoritative" palm-leaf manuscript (tālapatra) still available, the Nepal Manuscript (hereafter NM) has been the standard authoritative source for twentieth-century scholars of both Mithilā and Bengal by which later collections were assessed. This manuscript was first reported by Kāśī Prasād Jayasvāl in 1936 in the Government Library of Nepal (a.k.a. The Nepal Darbar Library). ${ }^{15}$ Later, the Maharaja of Darbhanga, Kāmeśvara Siṃha (1907-1964), sponsored two copies of the manuscript to be deposited in the Patna College Library and the Patna University Library.

This manuscript probably dates from the first half of the sixteenth century, though no date, location, or name of a patron or scribe is included in the text itself, which is written in the Maithili script, variously called

14 Winand M. Callewaert, with Swapna Sharma and Dieter Taillieu, The Millennium Kabir Vāñ̄: A Collection of Pad-s (New Delhi: Manohar Publishers \& Distributors, 2000), 1.

15 This palm-leaf manuscript consists of 108 folia. The last leaf is numbered as 109. Leaf number 104 is marked as number 105 in error. Each leaf is approximately $8 \times 2.25$ ". The Nepali label, which is superinscribed in Nepali Nāgarī, reads "Vidyāpati ko Gìta" ("the Songs of Vidyāpati”). Subhadra Jhā, The Songs of Vidyapati/Vidyāpati Gīt Sangraba (Banaras: Motilal Banarsidass, 1954), 115. 
Manuscript Studies, Vol. 4 [2019], Iss. 1, Art. 4

TABLE 1. Number of padas from the "Nepal Manuscript" also appearing in other sources.

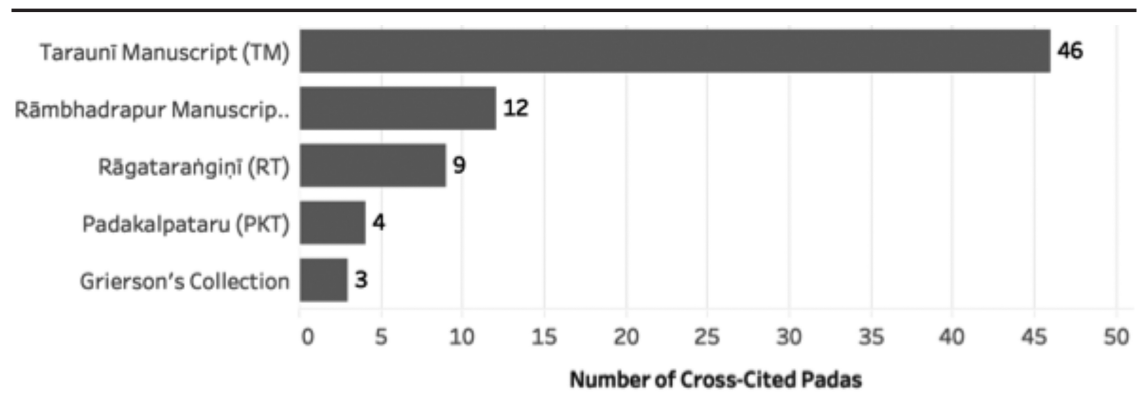

Mithilākșara or Tirbuta..$^{16}$ This manuscript contains 288 total padas, of which 261 are ascribed to Vidyāpati in the bhanitā. According to Subhadra Jha, a few stanzas are missing in various padas. He is clear that this is not due to any degradation of the manuscript but to scribal omission. He infers this from missing end-rhymes and interlinear poetic allusions. ${ }^{17}$

Twenty-six other poets' padas are included in this collection. Thirteen padas are ascribed to eleven different poets, and thirteen are unattributed. Rādhā-Krṣnna, Śiva, and Śakti are the focal subjects of the padas. The poems dedicated to Siva and Śakti/Devī (also called nacārīs) are usually said to be devotional, while the nominally Rādhā-Krnșna-centric padas are said to be more overtly erotic, mannerist, and courtly. Many twentieth-century collections of Vidyāpati's padas have included the padas of the NM with varying levels of acceptance and authority. Nagendranath Gupta's influential collection included 219 of the 261 padas. ${ }^{18}$ This edition has been influential for later editors in Bengali and Hindi language collections. A recently republished edition of the NM, by the Bibār-Rāstrabhāșā-Parișad, has made the task of collating occurrences of particular padas much easier. According to this edition, there are concurrences in other manuscripts as shown in Table $1 .{ }^{19}$

16 This script closely resembles the Bengali and Assamese scripts. Though contemporary Maithili is written in Nägarī, many Maithil Brahmins continue to cultivate Mithiläkșara for ceremonial and religious purposes.

17 Subhadra Jhā, Songs of Vidyapati/Vidyāpati Gìt Sangraba, 113-27.

18 Nagendranath Gupta, Vidyāpati Ṭākurer Padāvalī (Kalikātā: Baṅgìya Sāhitya Parișat, 1909)

19 Vidyāpati-Padāvalī, 1:389-98. 


\section{RĀMBHADRAPUR MANUSCRIPT}

The Rāmbhadrapur Manuscript (hereafter RM), discovered in the eponymous village in North Bihar, was the second major source of Vidyāpati's padas for twentieth-century scholars seeking to authenticate padas found in Bengali sources. It is regarded by some to be of equal age as the NM. This manuscript "disappeared" in the late 1980s, stolen from the archives at Patna University. Unfortunately, this "theft" is a common story for many manuscripts relating to the Vidyāpati tradition. ${ }^{20}$

From the description given in the Bibār-Rāștrabhāṣāa-Parișad's edition, we know that this palm-leaf manuscript was incomplete, missing the first ten folia. While only sixty padas include a bhanitā clearly attributing them to Vidyāpati, many later editors attribute a larger number of padas from this manuscript to Vidyāpati. Śivānanda Țhākur, in his well-regarded and conservative Viśuddha Vidyāpati Padāvalī (1938), cites forty of these padas, and Mitra and Majumdar's more wide-ranging collection includes ninetythree. $^{21}$

\section{TARAUnī MANUSCRIPT}

The Taraunī Manuscript (hereafter TM), also named for the village of its discovery in the Madhubanī district of Mithilā, was originally made available to several scholars in Calcutta by Mohinīmohan Gupta. Nāgendranāth Gupta eventually came to use the TM for his influential edition of Vidyāpati's Padāvalī.22 After completing his work, Gupta donated the manuscript to the

20 In a recent conversation, Raman Jha of the Department of Maithili at the Lalit Narayan Mithilā University in Darbhanga, Bihar, told me that most likely the manuscripts were destroyed, lost, or misplaced and that "theft" was a convenient excuse given by local bureaucrats and librarians. I cannot confirm or deny these claims, but it is likely due to the current state of these libraries. Sadly, this is the end of the investigative trail as far as the Mithilā-based manuscripts are concerned.

21 Vidyāpati-Padāvalī, 1:102-3.

22 Nāgendranāth Gupta, ed., Vidyāpati Țhākurera Padāval̄i (Kalikātā: Bañgìya-SāhityaParișat, 1909). 
Manuscript Studies, Vol. 4 [2019], Iss. 1, Art. 4

library at Calcutta University. Since then, the manuscript, like so many others, has been lost. Nāgendranāth Gupta's edition and a more recent edition by the Bibār-Raștrabhāṣā-Pariṣad are the only sources available for this manuscript. Because the manuscript is missing and because of an unclear publication history, there are a disputed number of padas in this text. Gupta cites that there were 231 padas, of which 101 clearly had Vidyāpati's bhanitā. ${ }^{23}$

\section{The Bengali Padāvalīs}

The padas of Vidyāpati and his successors in Bengal can largely be tied to the literary history and output of the Gaudīya Vaiṣnava followers of Caitanya (1486-1534). Caitanya himself is said to have enjoyed Vidyāpati's padas not as a rasika (connoisseur) of literature, but as a bbakta (devotee) by Krṣnạāāsa Kavirāja in the Caitanya-Caritāmrta. From the eighteenth to the nineteenth centuries, several large compendia of padas were assembled. These padāvalīs are distinct from their Maithili counterparts in their devotional and liturgical provenance. The language of these devotional anthologies of Bengal is usually said to be "Brajabuli," variously claimed as a dialect of Maithili, a Mischesprache or a Kunstsprache. There are varying opinions as to whether this is closer to Maithili or Bengali, but it is usually described as Maithili-inflected Middle Bengali used only in the context of devotional padas. An analogous tradition exists in Assamese (called "Brajavuli") and in Odiā. ${ }^{24}$ The tradition of Brajabuli literature in Bengal extends from the time of Vidyāpati until the late nineteenth century CE, when Bengali reformers began using contemporary Bengali as their preferred poetic medium.

Though most of the large Bengali pada collections contain thousands of individual padas by historically Maithili and Bengali poets, a much smaller number of padas can be traced directly from the older Maithili sources. Out of the more than three thousand padas in Vaiṣnava-dāsa's (née Gokulānanda

23 Vidyāpati-Padāvalī, 1:103-5.

24 Sukumar Sen, A History of Brajabuli Literature: Being a Study of the Vaisnava Lyric Poetry and Poets of Bengal (Calcutta: University of Calcutta, 1935), 1-10. 
Sen) Padakalpataru (late eighteenth century CE), only four padas can also be found in the NM, and an additional ten can be found in other Maithili sources. ${ }^{25}$ Other prominent Bengali/Brajabuli padāvalīs/pada-saṃgrabas include the Kṣaṇad̄̄ Gitacintāmaṇi (early eighteenth century CE), Radhāmohan Thākura's Padāmrta-Samudra (mid-eighteenth century CE), ${ }^{26}$ Dīnabandhu Dāsa's Sam̄kīrtanāmṛta (1771 CE), ${ }^{27}$ and the Kìrttanānada (likely early nineteenth century CE). ${ }^{28}$

\section{Additional Sources}

Two centuries after his death, Vidyāpati evolved from being merely a successful and popular local court poet to be the very standard by which Maithili lyric poetry was discerned and emulated. ${ }^{29}$ In addition to the padāvalīs, which are contextualized collections of padas, there are a few additional textual sources for Vidyāpati's padas. In the seventeenth century, Locanadāsa, under the order of either Narapati Țhākura or Mahinātha Ṭhākura (ca. 1690-1720 CE), composed a long treatise on the classical music of then contemporary Mithilā, focusing upon local regional variations of music and poetry, called the Rāgataraingin̄ ("Waves of Melody"). ${ }^{30}$ This

25 This is the largest Bengali/Brajabuli padāvalī. The bhanitās of 161 padas mention Vidyāpati. Mitra and Majumdar use only twenty-four padas.

26 Total 746 padas. Sixty-four padas are attributed to Vidyāpati by their bhanitās. Mitra and Majumdar use sixty of these padas.

27 Twenty-four poets with 491 padas. Ten padas are attributed to Vidyāpati. Of these, two are ascribed to the "Bengali Vidyāpati" by Mitra and Majumdar.

28 The date of the original manuscript is unknown, but the first printed edition was published in 1826. Of the 659 total padas of this collection, approximately 580 are attributed to Vidyāpati. Mitra and Majumdar included only thirty-eight in their edition.

29 Rāgataraìgin̄ 3.12-20.

30 Rāgatarañgiñ 1.7-8. Shashinath Jha, ed., Locanakṛtā Rāgatarañgin̄ì, (Pațanā: Maithilī Akādamī, 1981).

The verse is ambiguous as to whether Mahinātha commissioned the Rāgataranginin to honor his younger brother Narapati or Narapati himself commissioned the text. For a more detailed summary of this confusion, see Jayakanta Mishra, History of Maitbili Literature (New Delhi: Sahitya Akademi, 1976), 127-29. 
treatise in Sanskrit, Maithili, and Braj Bhasha describes the technical features of various rāgas (melodic structures), tālas (rhythmic cycles), candas (meters), and mātrās (metrical units/morae). The majority of the technical explanations are illustrated with Maithili padas. Vidyāpati features as the most prominent poet of this collection, with sixty-three padas. Twentyeight other poets are included in this collection, including the poems of the complier Locana-dāsa himself. It is clear from the prominence of Vidyāpati's padas that Locana incorporates them as exemplars of the tradition as a whole. Vidyāpati is also mentioned in the introductory verses of the third taraiga (lit. 'wave,' here 'section') of the text.

Another source often cited by contemporary Vidyāpati scholars is the "oral collection" of George A. Grierson. His 1882 grammar and chrestomathy include thirty-four padas of Vidyāpati that he recorded during his field research. ${ }^{31}$ Though I will not consider this collection here, it is important for the record of the popular historical performance tradition of Vidyāpati's padas before the complications of modern recording and distribution practices. This collection shows substantial linguistic divergence from the "classical" Maithili and embodies the non-textual tradition of pada transmission within Mithilā.

\section{A Comparison of Sources}

After considering the larger mapping of Vidyāpati's padas across Maithili and Bengali sources in several centuries from the precolonial period, a different sort of relationship has to be mapped between the manuscripts that remain. This is due to an unclear lineage of manuscripts and the current logistical problems of obtaining further evidence. Comparing one of the padas that exists with three of the older Maithili sources, one gets a sense of how the tradition of Vidyāpati expanded and commented upon itself within the very body of the padas. Because the tradition of Maithili/Brajabuli lyric poetry did not have a commentarial tradition until the modern period,

31 George Abraham Grierson, An Introduction to the Maitbili Language of North Bibár: Containing a Grammar, Chrestomathy and Vocabulary (Calcutta: Asiatic Society, 1881). 
the insights of minor textual variance and emendations deserve added attention.

\section{Three Overlapping Padas}

\section{NM (Song 24) $)^{32}$}

Vibbāsa Rāge-

Suraja sindura vindu cāndane lihae indu |

Tithi kahi geli tilake \|

Viparita abhisāra amiña galae dhāra

Añkasa kaela alake

|ldhruvapada\|

Mādhava bhețali pasāhana beri |

Ādhara haralaka puchiö na puchalaka |

Catura sakhijana melī \|

Ketaki dala lae campaka dala dae |

Kabarī thoelaka ānī |

Candane kuṁkume ańgaruci kaelaka

Samaya niveda sayānī ॥

$$
\text { Bhanaï Vidyāpatītyādi | }
$$

Trans. $^{33}$

In Rāga Vibhāsa-

The sun is a spot of vermillion and the moon is a spot of sandalwood written [upon her forehead].

The date has been told from her tilaka.

32 Vidyāpati-Padāvalī, 1:340-42.

33 All translations are my own unless otherwise noted. 
Manuscript Studies, Vol. 4 [2019], Iss. 1, Art. 4

A torrent of nectar flowing backwards,

She goads her hair into submission.

(Refrain)

Oh Mādhava! She has been encountered during the time of her adornment.

Stealing all her dignity without even asking,

Along with the group of her clever female companions.

Bringing ketaki leaves and placing the campaka petals,

They are brought and placed in her tied-up hair.

Her limbs are colored with sandalwood and vermillion.

Vidyāpati says this amongst other things.

\section{TM (Song 78) (34 $^{34}$}

Suraja sindura bindu camdane likhae indu

Tithi kahi geli tilake |

Viparita abhisāra amiya barisa dhāra

Ańkusa kaela alake ॥

(Refrain)

Mādhava, bhețala pasāhani beri |

Ādara haralaka puchiona puchalaka

Catura sakhī jana merī ॥|

Ketaki dala dae campaka phula laë

Kabarihi thoelaka ānī |

Mrgamada kuṁkuma ańgaruci kaëlaka

Samaya nibeda sayānī ॥

Bhanaï Vidyāpati Sunaha abhayamati

Kuhū nikața paramāne|

34 Śrī Gangānanda Simha, Sudhākara Sāātrī, Śrī Lakșmīpati Simha, Baladeva Miśra, and Jațāśṅkara Jhā, eds., Vidyāpati Padāvalī: Mithilā Mèn Upalabdha Vidyāpati Ke Padoì Kā Samigraha, 3 vols. (Pațanā: Bihāra-Rāșțrabhāṣā-Pariṣad, 2004), 2:301-2. 
Rājā Śivasiṃha rūpanarāyana

Lakhimā dei viramāne ${ }^{35} \|$

Trans.

The sun is a spot of vermillion and the moon is a spot of sandalwood written [upon her forehead].

The date has been told from her tilaka.

A torrent of nectar flowing backwards,

She goads her hair into submission.

(Refrain)

Oh Mādhava! She has been encountered during the time of her adornment.

Stealing all her dignity without even asking,

Along with the group of her clever female companions.

Bringing ketaki leaves and placing the campaka petals,

They are brought and placed in her tied-up hair.

Her limbs are colored with musk and vermillion.

The time is made apparent, oh clever lady!

Vidyāpati says, "Listen without fear!

It is plain to see that Amāvasyā is soon."

King Śivasiṃha is the very image of Narāyaṇa,

[And] is the Lord of Lady Lakhimā. ${ }^{36}$

\section{Rāgatarañgin̄ī (Song 26) ${ }^{37}$}

Ramyā Bhìmpalāsī-

35 This reading is most likely an error. The Rāgatarangin̄ $\bar{\imath}$ and the TM versions of this pada are virtually identical. The reading should be devi ramāne (husband/spouse). I have retained this variation as symptomatic of the problems of relying on printed editions of manuscripts that are no longer available to examine.

36 There is a Śleșa (pun or double-reading) that can be read here. Siva Simha is equated with Narāyaṇa (a.k.a. Viṣnu), and his wife Lakhimā figures equally as the goddess Lakṣmī (tatsama equivalent of Lakhimā), who is the spouse of Viṣnu.

37 Simha et al., Vidyāpati Padāvalī, 2:166. 
Manuscript Studies, Vol. 4 [2019], Iss. 1, Art. 4

Suraja sindura bindu cāndane lihae indu

Tithi kahi geli tilake |

Viparita abhisāra barisa amiña dhāra

Añkuśa kaela ti(la)ke \|

He Mādhava bhețali pasāhani beri|

Àdhara haralaka puchi (on ne puchalaka

Catura sakhi ja)na merill

Ketaki dala lae campaka phula daya

Kabarī phoelaka ānī |

Mṛamada kum̉kumeṃ ñagarucita laölaka

Samae niveda sayāṃni \|

Bhanaï Vidyāpati sunu varajauvati

Kuhu nīkața paramāne |

Rājā Śivasiṃha rūpanarāëna

Lakhimā devi $\operatorname{ram}(\bar{a})$ ne \|

Trans.

In [Rāga] Ramyā Bhìmpalāsī-

The sun is a spot of vermillion and the moon is a spot of sandalwood written [upon her forehead].

The date has been told from her tilaka.

A torrent of nectar flowing backwards,

She goads her hair into submission.

(Refrain)

Oh Mādhava! She has been encountered during the time of her adornment.

Stealing all her dignity without even asking,

Along with the group of her clever female companions.

Bringing ketaki leaves and placing the campaka petals,

They are brought and placed in her tied-up hair. 
Her limbs are colored with musk and vermillion.

The time is made apparent, oh clever lady!

Vidyāpati says, "Listen without fear!

It is plain to see that Amāvasyā is soon."

King Śivasiṃha is the very image of Narāyaṇa,

[And] is the Lord of Lady Lakhimā.

\section{What to Do with the Pothis?}

When shifting focus from the Maithili padāvalī manuscripts to the more plentiful and neglected Bengali pothis, several challenges arise. The sheer number of potbiss, their small size, the lack of contextual information, and the difficulty of collating the individual padas all make it difficult to undertake any sort of philological extrapolation of patterns of circulation and reception. Although manuscript collections in Bengal, such as the Manuscript Resource Centre at Calcutta University or the Bangīya-SābityaParișat, contain many hundreds of padāvalī potbīs, scholars pay little attention to them.

Evoking the prestige of the court of Siva Simpha and Vidyāpati is a unique feature of what many call the Vidyāpati tradition of padas. When adapted to the devotional Vaisnava context in Bengal, the courtly elements never entirely disappeared. While only a few dozen padas exist across the Bengali and Maithili manuscript sources, the bhanitās of Vidyāpati referencing his patron (and his qualities as connoisseur, or rasika) were maintained. W. L. Smith emphasized that the relative antiquity of Old Maithili (vis-à-vis Bengali, Assamese, or Odia) and the cultural memory of Mithilā as a center of Nyāya and Sanskrit studies in eastern India led to the enshrinement of Old Maithili poetic standards as part of the embodiment of that culture. ${ }^{38}$ While Smith and others have focused on the linguistic effects of this memory

38 W. L. Smith, Mirja Juntenen, William L. Smith, and Carl Suneson, eds., Brajabuli, Vrajāvalī and Maithili, Sauhrdyamangalam: Studies in Honour of Siegfried Lienhard on His 70th Birthday, (Stockholm: Association of Oriental Studies, 1995), 339. 
Manuscript Studies, Vol. 4 [2019], Iss. 1, Art. 4

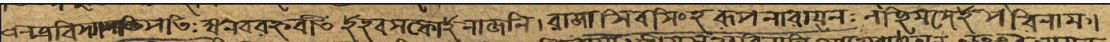

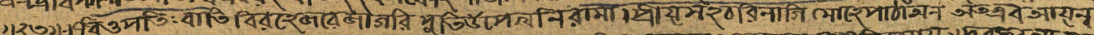

FIGU RE 1. Vaișnava Pada, Accession Number G4876. Kolkata: Asiatic Society, n.d.

tradition (a path of enquiry that needs further exploration), I propose that an analysis focused on specific cultural markers and clues of rhetoric within the padas can also be beneficial for understanding the process of vernacular literary memory and identity formations.

Moving onto one pothi-style held in the Asiatic Society in Kolkata, a "close reading" of the poetic-signature (bhanitā) of Vidyāpati reveals a link between the uniquely Bengali attestations of particular padas and the royal Oinvāra patrons of Vidyāpati in historical Mithilā. While I do not have permission from the Asiatic Society of Bengal to reproduce entire pages of the concerned nineteenth-century poth $\bar{\imath}$ in their entirety, a small selection of the bbanitā in this manuscript demonstrates a clear relationship between the Vaiṣnava Bengali Vidyāpati tradition and the original court of Vidyāpati and Śiva Simha.

Bhanae vidyāpati varayuvati iha vasa koī na jani |

Rāja Śiva Siṃha rupanārāyana Lachima dēi parināma \|23\|

Says Vidyāpati, "Oh best of the young women! There is no [other] such compulsion.”

The King Śiva Siṃha, the very image of Nārāyaṇa, Devī Lachima [sic] is his perfection.

The rest of the pada, not appearing in other padāvalì sources, could be dismissed as insignificant ephemera, but if we take the bbanitā seriously for a moment, clear structural and thematic connections to padas of the Maithili substrata of the Vidyāpati tradition are visible. Ignoring the linguistic irregularities of this closing distich of the pada, there are two elements directly parallel to the earlier example padas. Namely, that in the first hemistich, Vidyāpati beseeches the best of the youthful women, and in the second half, he evokes the figure of Śiva Simpha. 
A "throwaway" pada in a "throwaway" nineteenth-century pothi can tell us about how the poets and audiences, removed from Vidyaapati by time, region, and linguistic variance, thought of the poet within their own literary and cultural history. Invoking the names of Vidyāpati and Śiva Siṃha also has the effect of elevating purely devotional-oriented (bhakti) padas to the realm of high or courtly literature. This pothi, like dozens of others, also contains the padas of Govinda-dāsa (1535-1613), often called the second Vidyāpati, though usually taken as more overtly Vaiṣnava than Vidyāpati. The combination of Vidyāpati and Govinda-dāsa's padas within a single small pothi has the effect of devotionalizing Vidyāpati's padas and literarizing the padas of Govinda-dāsa by mutual association. This pairing of Vidyāpati and Govinda-dāsa (and in other cases Caṇ̣̂̂̄-dāsa) was exceedingly common in nineteenth-century padāvalīs. The manuscript collection at Calcutta University contains more than two dozen such small pothis. Many more are scattered and neglected in other collections.

One of the largest accessible collections of pothi-style collections of Vaișnava padāvalīs is the manuscript library of Calcutta University. Alongside roughly two dozen edited Bengali/Brajabuli volumes, like the Padakalpataru, this manuscript collection holds nearly seventy-five small potbi-style manuscripts. Facing the challenges of a physically degraded archive, a large number of fragmented manuscripts, and colophons that are either missing or not supplied makes it difficult to divine textual patterns or literary associations. For example, taking a step back and performing a "distant reading" of the archive collection as a whole, one can understand the way that BengaliGaudīya poets imagined Vidyāpati to feature in their own tradition.

In Table 2, one can see all of the potbī-style Padāvalīs in the Calcutta University Manuscript Collection that feature both Vidyāpati and at least one other Maithili/Brajabuli poet. It is clear that there is a much stronger association between Vidyāpati and his fellow Maithili poet Govinda-dāsa and another pre-Caitanya poet Caṇ̣̂i-dāsa than other late-period Brajabuli poets with clearer Gaudīya identities. While definitive conclusions about the imagined history of Vidyāpati in the Bengali/Brajabuli canon cannot be drawn from a sample reading like this, it can help to nuance qualitative "close readings" and to understand their place in the archive. 
Manuscript Studies, Vol. 4 [2019], Iss. 1, Art. 4

TABLE 2. Poets featured in Calcutta University Manuscript Library's Padāvalī collection alongside Vidyāpati.

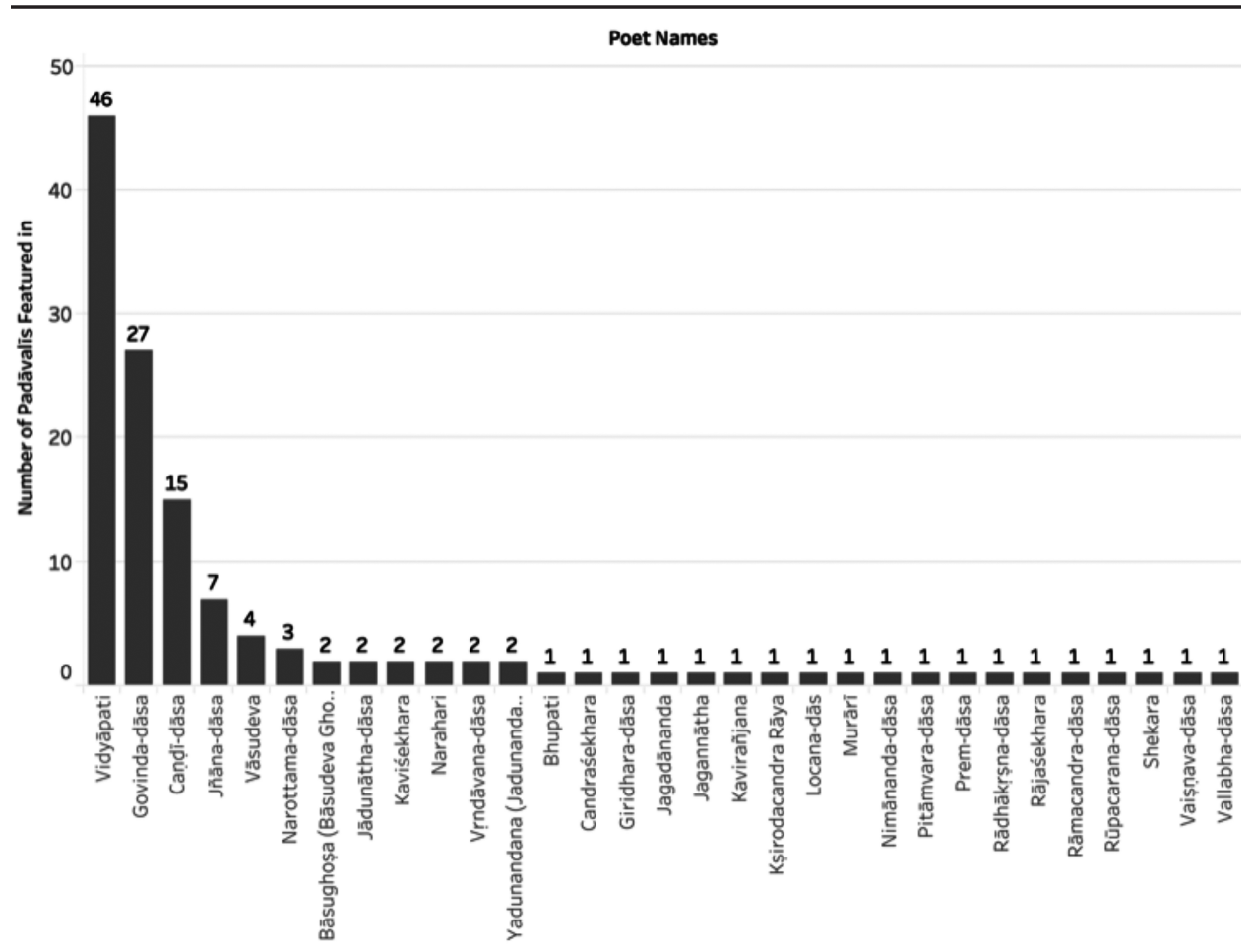

\section{Toward a New Perspective}

Many have begun to question the utility and feasibility of finding any premodern poet in their pristine, original Ur-state. ${ }^{39}$ This challenge to traditional

39 In the case of the Kabir tradition, Strnad advocates for considering manuscripts of different poetic genres ( $p a d a s$ and $s \bar{a} k b \bar{\imath}$ ) and sectarian affiliations to develop a more inclusive map of manuscript production and consumption. Strnad recommends such an approach without even considering sources outside the manuscript tradition. See Jaroslav Strnad, Searching for the Source or Mapping the Stream?: Some Text-Critical Issues in the Study of Medieval Bhakti, Tyler Williams, Anshu Malhotra, and John Stratton Hawley, eds., Text and Tradition in Early Modern North India (New Delhi: Oxford University Press, 2018), 143-58. 
methods and attitudes can help to shift the conversation and focus when considering poets like Vidyāpati who have complex histories of memorialization that sometimes obscure the ability to map the paths of transmission and circulation. Instead of finding an "original” Vidyāpati or ignoring the Bengali/ Brajabuli Vidyāpati for the lack of corresponding sources, the new task becomes mapping trajectories and signifiers of memory construction and appropriation. This manner of examining manuscript trajectories based on both textual history and a history of memorialization can also help to conceptualize the more abstract aspects of developing vernacular identities in eastern South Asia over the last half millennium and premodern traditions of lyric poetry more generally.

For the particular case of Vidyāpati and the tradition that was constructed around him (both poetic and narrative), instead of removing focus from the manuscripts as the primary site of investigation, accessing additional sites of memorialization, whether it be song, film, or physical monuments, expands the number of manuscripts that could be considered as viable sites of critical examination. What has happened is the complete disregard or segregation of the Bengali/Brajabuli Vidyāpati tradition from the Maithili manuscript sources. This is completely at odds with the selfperception of the tradition itself, which maintains its own historical and linguistic continuity. Tracing both the disjunctions and intersections between the tradition's self-perception and the manuscript evidence becomes the object of study that evinces more realistically productive pathways of inquiry. This article is only a summary of the status quaestionis of the current state of Vidyāpati studies. Much remains to be done even through purely textual/ philological studies. Even so, the stagnating field of Vidyāpati studies can be refreshed and opened to many more perspectives with a few of the suggestions of this study. 